\title{
Digital Issue Movements: Political Repertoires and Drivers of Participation among Belgian Youth in the Context of 'School Strike for Climate'
}

\author{
Cato Waeterloos ${ }^{1,2, *(D)}$, Peter Conradie ${ }^{2,3}$, Michel Walrave ${ }^{4}$ and Koen Ponnet ${ }^{1,2}$ (D) \\ 1 Department of Communication Sciences, Ghent University, 9000 Ghent, Belgium; Koen.Ponnet@ugent.be \\ 2 imec-mict-UGent, Ghent University, 9000 Ghent, Belgium; peter.conradie@ugent.be \\ 3 Department of Industrial Systems Engineering and Product Design, Campus Kortrijk, Ghent University, \\ 8500 Kortrijk, Belgium \\ 4 Department of Communication Sciences, University of Antwerp, 2000 Antwerp, Belgium; \\ Michel.Walrave@uantwerpen.be \\ * Correspondence: Cato.Waeterloos@ugent.be; Tel.: +32-9-264-67-33
}

check for

updates

Citation: Waeterloos, C.; Conradie, P.; Walrave, M.; Ponnet, K. Digital Issue Movements: Political

Repertoires and Drivers of

Participation among Belgian Youth in the Context of 'School Strike for

Climate'. Sustainability 2021, 13, 9892.

https://doi.org/10.3390/su13179892

Academic Editors: Elvira Cicognani and Maria Fernandes-Jesus

Received: 30 June 2021

Accepted: 1 September 2021

Published: 2 September 2021

Publisher's Note: MDPI stays neutral with regard to jurisdictional claims in published maps and institutional affiliations.

Copyright: (c) 2021 by the authors. Licensee MDPI, Basel, Switzerland. This article is an open access article distributed under the terms and conditions of the Creative Commons Attribution (CC BY) license (https:// creativecommons.org/licenses/by/ $4.0 /)$.

\begin{abstract}
It often remains unclear how young citizens are combining various forms of political participation, as well as why they choose some over others, especially within a single-issue movement. Moreover, little is known about how social networking sites (SNS) fit into the political repertoires of citizens. Therefore, this study explores youths' political participation patterns in the context of the 2019 youth-led climate strikes. We rely on data from a paper and pencil survey among 498 high school students in Belgium. To identify different types of activists, the study used latent class analysis (LCA). In addition, a multinomial logistic regression was conducted to assess how identified participation types differ from each other. Four different participation repertoires regarding the climate issue were identified, each distinctive in the way they rely on different forms of political participation. In addition, membership to each of the different classes is associated with a unique set of characteristics (in terms of political efficacies, climate issue involvement, and online expression motives). The article shows how SNS make up a crucial part of youths' issue-specific participation patterns and sheds light on the mechanisms underlying their participation choices within the climate movement.
\end{abstract}

Keywords: political participation; youth; political repertoires; climate movement; school strike for climate; latent class analysis; social media; protest; political efficacy; single-issue movement

\section{Introduction}

Citizens' ways of engaging in civic society have undergone significant changes in postindustrial societies. A variety of studies indicate how citizens have moved beyond mere engagement in institutional politics and are often engaging in diverse forms of participation, such as protesting, consumerism, or volunteering [1-5]. Furthermore, social networking sites (SNS) allow for more personalized, fluid, and creative outings of citizenship [6,7]. Youth in particular seem to be longing for more customized forms of engagement [1]. That is, they seem more willing and able to pick and choose from various social issues that interest and affect them, without the need for intermediary organizations or parties [8,9].

Characteristic of these emerging forms of citizenship is the desire to 'think globally' but 'act locally' [10]. This has become especially apparent within the climate movement and, more specifically, the recent worldwide climate strikes [11]. Over the course of 2018 and 2019, a youth-led climate movement became the centre of political and media attention. Led by the Swedish teenager Greta Thunberg, the 'School Strikes for Climate' called on youth to skip school and demand far-reaching governmental action on climate change. The protests quickly developed into a global movement that accelerated youth climate mobilization in an unprecedented scale [12]. In Belgium, an action group called Youth For Climate was formed by two teenagers (Anuna De Wever and Kyra Gantois) to coordinate 
the protests. As such, Belgium would become one of the first European countries to organize the strikes with among the highest participation numbers [13]. Therefore, the current study relies on the case of the 2019 climate strikes, in order to gain insight in the issue-specific political participation among youth in Belgium.

Most prior research towards citizens' changing political habits seems to focus on the predictive relationship between online media use and offline political engagement [14] or solely on digital forms of participation [15]. Few empirical studies, however, employ a repertoire-based approach to assess how citizens choose and combine the various available modes of political action, especially within a specific single-issue movement (such as the climate movement). A considerable amount of work regarding participation repertoires has been conducted by Jennifer Oser $[4,16,17]$. She argues how the increased prevalence of political participation beyond the electoral arena elevates the need for improved research designs, which shift the unit of analysis from a single participatory act towards the combination of different action forms. In this regard, she proposes Latent Class Analysis (LCA) as a statistical technique for the study of political participation patterns.

Only a handful of studies have relied on this technique to empirically identify these unique participation repertoires $[4,18,19]$. Still, these studies often focus exclusively on either offline or online forms of action. In other words, despite recent studies acknowledging the unique and independent character of political participation through SNS [19-21], a systematic understanding towards how these acts are combined with offline forms of participation (e.g., volunteering or protesting) is still lacking. Therefore, our first research question asks which different types of activists can be identified based on their participation repertoires towards the climate issue (by considering an extensive set of offline forms of participation as well as SNS participation through Facebook).

In addition, little is known about why people differ from each other in terms of these repertoires, and why citizens prefer certain modes of participation over others. Research towards the attitudes and motivations underlying political SNS use remains scarce [22], and oftentimes these newer forms of political participation have not been measured adequately [23]. To tackle these gaps, our second research question asks how different types of climate activists differ from each other in terms of different political and issue-specific characteristics (i.e., efficacy beliefs, climate issue involvement, and motivations for online self-expression).

A final gap that is addressed is the overall lack of political participation studies focusing on specific youth populations, apart from relying on university student samples [19]. Overall, youth's political repertoires have been understudied and it often remains unclear how various forms of action are combined within these repertoires, especially within the same single-issue movement [24]. Therefore, the current study was conducted among 498 high school students in Flanders, Belgium using a paper and pencil survey.

\subsection{Changing Citizenship in a New Media Context}

According to Vromen [5], a 'new participatory turn' has taken place in the literature, which acknowledges the changing nature of political participation and citizenship. Three main commonalities are assumed to define this participatory turn. First, a focus on political targets beyond the state and the development of alternative or non-formal institutional spheres for collective action. Second, an analysis of everyday, ad hoc or project involvement, rather than long-term ideological allegiance and/or membership; and third, an acknowledgement of the role individualization plays in social and political interactions.

New citizenship norms are understood to underly these changing participation patterns. They refer to a shared set of expectations and values about how democracy functions and citizen's role in politics [2,25]. Often, a distinction is drawn between 'actualizing' or 'engaged' citizen norms on the one hand, and 'duty-based' norms on the other. Dutiful citizenship describes more traditional notions of good citizenship, which mainly include engagement in conventional, institutional forms of political participation. Here, voting is the core democratic act. Actualizing citizens, in contrast, have a higher sense of individual 
purpose and therefore prefer loose networks to engage in social and political action [26,27]. They favor political autonomy and seek out more individualized, direct forms of action away from elections and political parties [2]. This is similar to what Bang [10] calls 'everyday makers', describing a form of citizenship that is highly individual and project-oriented. Everyday makers want to decide when to act on certain issues, and maybe more importantly, when not to, by dealing with common concerns in a concrete and personal manner. Nonetheless, despite concerns about declining levels of dutiful norms, recent studies have shown how different citizenship norms do not necessarily exclude each other. Rather, these qualities tend to function in a complementary manner, as not every citizen adheres strictly to only one understanding of citizenship (e.g., [27,28]).

The 'participatory turn' described above seems to have emerged parallel with changes in the media landscape and, consequently, media habits. As Mihailidis \& Thevenin [29] (p. 1) note, "present-day discussions on the tenets of citizenship cannot avoid including the role of media in civic participation and engagement". Key affordances of digital and social media fit current notions of citizenship particularly well and have been linked with novel forms of political participation [30,31]. For instance, it has been argued that interaction with online, interactive media, and endorsing actualizing citizenship norms and activities work as a 'reinforcing spiral'. As such, new media are considered an important means for negotiating citizenship [27,32].

One framework that both acknowledges the rise of personalized politics and identifies digital media as central organizing agents for political action, is the logic of connective action $[6,33]$. Within this logic, taking political action is self-motivated and centers around the personal appropriation of common themes and issues, such as climate change or women's rights. Digital communication technologies, and SNS in particular, are considered crucial enablers of these new politics. The central and immediate nature of these platforms allow citizens to inform themselves on the issues that interest them and act on these issues instantly, hereby lending itself to forms of opt-in, ad hoc citizenship [34]. In addition, new media allow for the formation of a shared narrative, through the individual posting, sharing, and remixing of content. As such, they align with the views on citizens as action-oriented creators and communicators, beyond their participation in institutional politics [27,29].

Early work by Brunsting \& Postmes already addressed the changing nature of collective action due to the Internet and argued how online political actions are qualitatively different than their offline counterparts [35]. Indeed, many authors have come to recognize online outings of new citizenship as independent participatory acts. According to Theocharis [7], for example, the elements of self-expression and personalization are crucial elements of digitally networked participation (DNP), which entails both the activation of one's own network as well as the personal appropriation of content to convince others in relation to a social or political cause. In the context of the recent climate strikes, the particular role of social media has also been acknowledged. These platforms allowed citizens within the movement not only to voice their concerns and disclose information, but also to document their discontent by connecting disparate local protest events to a larger, global movement [11].

\subsection{Young People's Political Participation and Repertoires}

The interplay between new media and new citizenship norms have made studies in political communication especially attentive towards engagement among youth. Adolescence is a critical life-stage in the context of political socialization, characterized by uncertainty and fluidity [36]. In this regard, youth participation is considered a continuous process that involves exploration and change over time. Additionally, it constitutes an important part of young people's general development in terms of their identities, values and beliefs [1,37].

Yet, early studies in the field have often described youth as politically apathetic, cynical, and disengaged, because of their declining participation in institutional politics [38,39]. These criticisms are often driven by a too narrow conceptualization of what could be 
considered 'political participation' and by neglecting the ways in which emerging modes of action could be combined [40]. Moreover, following the proliferation of SNS, various scholars raised concerns about the susceptibility of young people to so-called 'slacktivism', referring to online forms of low-effort, low-impact political participation. Central to this view is that engagement in these types of participation would cause people to dismiss other offline forms of action and thus, enlarge the assumed gap between those who "practice real politics" and younger generations [41,42].

Over the years, a more nuanced view has emerged, where youth are not considered disengaged, but rather 'differently engaged'. They tend to navigate within a broader spectrum of participatory activities, while at the same time becoming more selective in their political choices $[2,43]$. Indeed, cause-oriented political interest is especially dominant among young people. Several studies have provided evidence for youths' interest and engagement in political causes with an everyday life and ethical component. In other words, young er citizens prefer to engage primarily with issues that interest and impact them [8,44,45]. This line of thinking is extended in the work of Andersen et al. [46]. The authors discuss how, contrary to older generations, the connection between news and participation patterns among youth is not continuous. Instead, it shows similarities with "the trace of a heart on a hospital monitor, where spikes of different amplitude alternate with rest periods" (p. 139). This corresponds with understandings of emerging citizenship and participation as being more short-term, spontaneous, and cause-oriented. However, this is not to say that collective forms of action have no relevance within youth political participation, nor have 'digital natives' unanimously adopted newer forms of participation, such as digitally networked participation [19,46]. A recent study by Ekström \& Sveningsson [1] among 17- and 18-year-olds, indicates how they are both involved in more ad hoc as well as conventional political organizations, but that the nature of their engagement is tentative, rather than settled. Interestingly, young people in the study often remained skeptical towards the use of SNS as political tools.

In order to properly capture the current conditions and ways in which participation occurs, the study of participation repertoires has gained academic attention. These repertoires unite the available forms of participatory behaviours for citizens [47-49]. Whereas early studies were mainly concerned with measuring voting behaviour (see [50] for an overview), over the years, attention has shifted towards participation beyond the ballot box, such as protest behaviours, lifestyle politics [51], consumerism [52], craftivism [53], and digitally networked forms of participation [7]. Capturing political repertoires (i.e., how citizens choose to engage with the various available modes of political action), allows researchers to grasp the state of participatory democracy in a more accurate manner. And thus, by incorporating various participatory modes into research designs, a biased literature can be avoided $[4,54]$.

Most studies using a repertoire-based approach, have shown how different forms of political action tend to coexist, rather than cannibalize one another. It seems that participation patterns are becoming increasingly hybrid and individualized as they combine different types of participation $[4,17,18]$. In a study addressing a Belgian climate movement, De Moor, Marien \& Hooghe [24] found that forms of lifestyle politics often exist within complex political repertoires that also include state-oriented forms of action.

Contrary to what is often assumed, youth also tend to engage in a variety of social and political activities, online and offline (e.g., $[55,56])$. For instance, following interviews with high school and university students, Maher \& Earl [57] concluded that online and offline forms of activism are not mutually exclusive. Rather, digital media seem to 'innervate' youth participation. That is, these platforms not only provide important pathways towards offline political action (such as protests), but also give rise to unique, individualized forms of political participation within these online spaces [57,58]. Furthermore, Keating \& Melis [19] provided evidence for the existence of diverse participation patterns among youth, even when exclusively considering SNS participation. 


\subsection{The Current Study}

Drawing from literature that acknowledges changing citizenship norms, participation repertoires and media habits among youth, the present study aims to analyze which different participation patterns exist among Belgian high school students regarding the climate issue. Latent class analysis (LCA) is used to identify different types of climate activists based on their engagement in both offline forms of political participation, as well as through Facebook. As argued by Waeterloos et al. [23], Facebook constitutes a central platform for political expression and participation. Its technological and social affordances provide a unique space for participation, by allowing to create events, closed groups, posts, and pages $[59,60]$. These affordances are especially relevant as they fit central action modes of the climate movement under study [12]. In addition, Facebook remains the biggest SNS platform in Belgium in terms of active users [61], with $66 \%$ of 16-18-year-olds using Facebook at least once a week [62]. In addition, we employ multinomial logistic regression to assess which psychological characteristics differentiate these activist types from each other. We discuss these briefly below.

\subsubsection{Political Efficacies}

One of the predictors of interest in this study is political efficacy, which refers to feelings of competency and beliefs that one's political actions are consequential [63]. The concept of self-efficacy is rooted within social cognitive theory and concerns judgements about how well one can execute certain courses of action required to deal with prospective situations or produce certain outcomes [64,65]. In this regard, Bandura [66] states that all motivational factors to action are rooted in the belief that one has the power to produce effect by one's outcomes. Political efficacy then, is generally understood as having two components. Internal efficacy refers to beliefs about one's own competence to understand and participate in politics, whereas external efficacy concerns beliefs about the responsiveness of the government to citizen demands [67].

In general, political efficacy beliefs are often cited as one of the key predictors of political participation, alongside political interest and knowledge $[68,69]$. Indeed, various studies have proven the importance of internal and external efficacy perceptions in explaining various types of political behaviour, both offline and online (e.g., [70-73]). When considering youth in particular, the school context is considered crucial in fostering political efficacy beliefs, which could lead to increased democratic participation [74,75]. However, several authors have pointed to the inconsistencies in the application of political efficacy measures throughout the literature. Given that the concept of political efficacy is highly contextual, it should be adapted to the context and behavioral activities under study $[76,77]$. While some recent studies have employed specific efficacy measures targeted towards online behaviours (e.g., [22,70,78]), little is known about how different efficacy beliefs are related to specific participation patterns, especially when targeted towards a specific social or political issue. Therefore, drawing from the work of Velasquez \& LaRose [79], this paper includes four different types of efficacy (internal political efficacy, collective cause efficacy, social media internal political efficacy, and social media collective efficacy), tailored to both the social media modes of action, as well as the issue movement in which the political actions are embedded.

\subsubsection{Issue Involvement}

Scholars have argued how issue-specific political participation is likely motivated by different, issue-specific motivations compared to general political participation [80]. As such, our study assesses the role of issue involvement in determining individual participation repertoires. Issue involvement refers to the level in which a certain cause or issue is of personal significance to an individual [81]. As people believe a certain issue to be more salient or personally relevant, they are believed to be more likely to speak out on the topic and engage in collective action. Diverse studies have suggested 
positive associations between issue involvement and online political participation and expression [82,83], issue-related voting [84], and protest participation [85].

In the context of climate activism, those who are highly engaged with the issue of climate change and have strong opinions on the matter are more easily mobilized to commit to climate-related action $[80,86]$. In the literature, these citizens are referred to as 'issue publics': small groups of people who are intensely concerned and interested in particular issues, but not necessarily in others [84]. Indeed, Roser-Renouf et al. [87] showed how climate-related issue involvement, in terms of environmental concern and personal importance, was associated with both opinion leadership and offline climate activism. Similar studies indicated how specific environmental concerns are predictive of offline climate activism [88], including participation in the worldwide climate strikes [89].

Drawing from the conceptualization of issue publics, as well as literature on climaterelated activism, the current study includes climate change concern and endorsement of an ecological worldview as indicators of personal issue involvement $[90,91]$.

\subsubsection{Motivations for Online Participation}

In general, research has been inattentive to what is called the 'demand side' of political participation, which captures individual motivations and abilities to participate politically [92]. Several scholars have pointed to the need to explore the cognitive pathways that lead to specific forms of political action [93]. In this regard, Hoffmann \& Lutz [22] argue how a differentiated understanding of why people participate, is still lacking, especially online. Indeed, most studies towards online forms of participation, have considered these acts as pathways towards different, often offline participatory behaviour. Consequently, little is known about the possible unique motivations underlying participation on SNS $[23,94]$.

According to Gil de Zúñiga et al. [95], two different motivational routes lead towards citizen participation. While these routes focus on motivations for political discussion in particular, they provide a useful basis for examining motivations for participation as well. The first route is a social one, which includes motivations such as passing time and getting to know others. The civic motivational route on the other hand, refers to motivations such as persuading others, forming opinions, and keeping informed. Winter \& Neubaum [96] propose a similar distinction in their study. The social component is represented by the motive of creating a positive self-presentation, which was found to be positively associated with political opinion expression on social media. Additionally, two civic motivations were identified: a motive of disseminating information through online political expression and a motive of persuading others. However, only the former was found to be associated with online expression.

In any case, as political SNS use has become increasingly diversified, the underlying motivations are likely to be equally so [94]. Therefore, the current study assess how three prominent motivations for online political expression (disseminating information, persuading others, and creating a positive self-presentation) are associated with individual political repertoires [96].

\section{Materials and Methods}

This study uses data from a paper and pencil survey conducted among 689 high school students in Flanders, Belgium between April and June 2019. All students were between 15 and 19 years old $(\mathrm{M}=17.14 ; \mathrm{SD}=0.83)$. Our sample included students from three different education types, being general $(n=273,54.82 \%)$, vocational $(n=56,11.24 \%)$, and technical secondary education $(n=169,33.94 \%)$. After omitting questionnaires that were handed in empty and checking for systemic patterns in the missing data, these were listwise deleted, resulting in a final dataset of $n=498$. Girls comprised $41 \%$ of the final sample $(n=204)$.

Participants were recruited from eight different high schools. In total, 83 Dutch-speaking schools were contacted and asked whether they were interested in participating in the 
study. After the school principal formally agreed to participate, the school provided the researchers with a list of the different class groups and teachers that were willing to participate, and a date was discussed to conduct the survey. Each student and parent received a letter stating the purpose and voluntary character of the study. The students were not offered any incentives, but the participating schools were offered a report and guest lecture regarding the findings of the study. An informed consent was asked from the students and they were ensured that their results would remain anonymous and confidential. No personally identifiable information was collected. Moreover, our study was approved by the Ethics Committee of Ghent University.

\subsection{Measures}

\subsubsection{Socio-Demographic and Control Variables}

Respondents were asked about their age, sex $(0=$ male; $1=$ female $)$, and perceived economic strain. The latter was measured using four items [97,98]. An example item was "Our family doesn't have enough money to buy new clothes". Responses were captured using a Likert scale ranging from 1 (totally disagree) to 6 (totally agree) and averaged into a sum scale $(\alpha=0.89 ; \mathrm{M}=1.61 ; \mathrm{SD}=0.86)$. Furthermore, we controlled for the schools' 'climate strike policies' in the logistic regression. This was done by asking the principal of each participating school whether the school had a specific policy regarding their students' participation in the climate strikes during school hours. Based on the answers, a variable with three categories was created: a policy where participating in a strike was not allowed $(n=154)$, a policy where participation was allowed if students could prove their participation $(n=210)$, and a policy where participation was allowed without the need to prove strike attendance $(n=134)$.

\subsubsection{Political Participation Variables}

The questionnaire included 18 different, self-developed participation variables, covering both offline as well as social networking site (SNS) participation (through Facebook).

Six items represented offline participation, as to describe the various ways in which citizens can engage in offline political participation regarding the climate issue, such as protesting, donating money, or volunteering. SNS participation was captured using two subscales of the Social Media Political Participation Scale [23]. The scale is a validated and reliable measure to capture different forms of political participation on social media. For this study, two of the subscales were chosen to include in the survey: expressive and follower participation. Both constructs assess political participation on Facebook by taking the affordances of the platform into account, but differ from each other in capturing different 'levels' of participation. Expressive participation describes forms of political content creation on Facebook initiated by the user. It was measured using seven items. Follower participation in turn, describes participation where the user commits to a certain observable act on Facebook, but the user is not the creator of the original content nor the instigator of the action. The construct was measured by five items.

For each of the items, respondents were asked how often in the past 6 months they had done any of the described behaviours. Responses were captured using a Likert scale ranging from 1 (never) to 5 (very often). A list of the used items and their descriptives can be found in Table 1.

Table 1. Descriptives of the political participation variables.

\begin{tabular}{ccc}
\hline Participation Type & M (SD) & \% Participated \\
\hline Offline participation & & \\
\hline I participated in a protest, march or manifestation for the climate on a school day & $1.43(0.80)$ & 27.9 \\
I participated in a protest, march or manifestation for the climate during the weekend or a holiday & $1.22(0.62)$ & 13.1 \\
I volunteered in the context of the climate issue (e.g., participated in a clean-up, hung & $1.31(0.68)$ & 20.3 \\
up posters, ...) & $1.24(0.64)$ & 15.5 \\
\hline Signed an offline petition in the context of the climate issue &
\end{tabular}


Table 1. Cont.

\begin{tabular}{|c|c|c|}
\hline Participation Type & M (SD) & $\%$ Participated \\
\hline Donated money to an organization dedicated to the climate issue (locally or internationally) & $1.28(0.68)$ & 17.9 \\
\hline Contacted a politician or public figure offline in the context of the climate issue & $1.07(0.39)$ & 4.2 \\
\hline \multicolumn{3}{|l|}{ Expressive participation } \\
\hline $\begin{array}{c}\text { I posted or shared something (status, meme, link, ...) concerning the climate issue in a way that } \\
\text { was publicly visible }\end{array}$ & $1.41(0.86)$ & 23.5 \\
\hline I commented on something concerning the climate issue in a way that was publicly visible & $1.28(0.69)$ & 17.5 \\
\hline I trolled in the context of the climate issue & $1.30(0.81)$ & 15.7 \\
\hline $\begin{array}{c}\text { I sent something relating to the climate issue to someone in a private message on } \\
\text { Facebook/Messenger }\end{array}$ & $1.96(1.14)$ & 51.8 \\
\hline $\begin{array}{c}\text { I posted or shared something (status, meme, link, ...) concerning the climate issue in a closed } \\
\text { Facebook group }\end{array}$ & $1.55(0.98)$ & 30.5 \\
\hline I commented on something concerning the climate issue in a closed Facebook group & $1.53(0.92)$ & 31.5 \\
\hline $\begin{array}{l}\text { I liked something or reacted with an emotion on something concerning the climate issue in a closed } \\
\text { Facebook group }\end{array}$ & $1.80(1.14)$ & 41.0 \\
\hline \multicolumn{3}{|l|}{ Follower participation } \\
\hline \multirow{2}{*}{$\begin{array}{l}\text { I shared, spread a Facebook event or invited people for it in the context of the climate issue } \\
\text { I indicated that I would attend or was interested in a Facebook event in the context of the } \\
\text { climate issue }\end{array}$} & $1.19(0.58)$ & 11.8 \\
\hline & $1.53(0.91)$ & 32.5 \\
\hline I signed a petition on the climate issue after I saw it on Facebook & $1.34(0.75)$ & 20.3 \\
\hline I shared a petition on Facebook on the climate issue which was organized by someone else & $1.18(0.56)$ & 11.0 \\
\hline I became a member of a Facebook group concerning the climate issue & $1.21(0.61)$ & 13.1 \\
\hline
\end{tabular}

\subsubsection{Independent Variables}

Political efficacies. Internal political efficacy was measured using a five-point Likert scale $(1=$ not at all; $5=$ completely), asking the respondents to which extent they believe that they can influence government decisions $(\mathrm{M}=2.09$; $\mathrm{SD}=1.00)$ [71]. Similarly, drawn from the work of Roser-Renouf et al. [87], collective cause efficacy asked "To which extent do you believe that we as people can solve the climate issue?" $(1=$ not at all; $5=$ completely; $\mathrm{M}=3.50 ; \mathrm{SD}=0.94)$. Social media internal political efficacy was captured using nine items that were averaged to create a sum scale [77]. Respondents were asked "How certain are you that you can accomplish the following using social media?" ( $1=$ not at all; $5=$ completely). Example items were "influence others on political topics" and "use social media applications to obtain a political objective" $(\alpha=0.93 ; \mathrm{M}=2.79 ; \mathrm{SD}=0.89)$. Finally, social media collective efficacy assessed the belief that the climate movement as a whole could achieve certain political goals using social media platforms [79]. The scale consisted of five items, asking respondents "How certain are you that the climate movement can achieve the following by using social media?" $(\alpha=0.92 ; \mathrm{M}=3.60 ; \mathrm{SD}=0.88)$. Example items were "convince others to support the movement" and "coordinate the movement's activities and actions".

Issue involvement. Involvement with the climate issue was assessed using the revised NEP-scale (New Ecological Paradigm), which is a validated scale to assess the endorsement of an ecological worldview [91]. The NEP-scale consists of 15 items, each tapping into different theoretical facets of an ecological worldview. Example items are "if things continue on their present course, we will soon experience a major ecological catastrophe" and "plants and animals have as much right as humans to exist" $(1=$ totally disagree; $5=$ totally agree; $\alpha=0.79 ; \mathrm{M}=3.67 ; \mathrm{SD}=0.53$ ). In addition to the NEP-scale, we included a question to assess environmental concern [90]. Specifically, respondents were asked how concerned they are about the environment and climate change $(1=$ not at all concerned; $5=$ very concerned $)$ $(\mathrm{M}=3.65 ; \mathrm{SD}=0.97)$.

Motivations for opinion expression on social media. Respondents were asked about their motivations to engage in the different types of SNS participation, if they had done so ("To which extent do you do these things to ..."). The question was followed by 
14 different motive items to rate on a five-point Likert scale ( $1=$ not at all; $5=$ completely). A sum scale was created for each of the three distinct motives. The motive of disseminating information was measured by six items $(\alpha=0.95 ; \mathrm{M}=1.89 ; \mathrm{SD}=1.02)$. An example item is "...to inform my friends about the climate issue". The motive of persuading others was captured using three items $(\alpha=0.92 ; \mathrm{M}=1.86$; $\mathrm{SD}=1.02)$. Here, an example item is "... to convince others of my opinion toward the climate issue". Finally, the motive of self-presentation was measured by five items $(\alpha=0.92 ; \mathrm{M}=1.67 ; \mathrm{SD}=0.85)$. An example is "... so that other people notice how much I know about the climate issue".

For each of the created sum scales, the Cronbach's alpha coefficients were well above the 0.70 threshold, indicating good internal consistency.

\subsection{Analytic Strategy}

Our overall analytic strategy closely follows prior political research [16,99]. We first performed a latent class analysis (LCA) on different behavioral variables to identify underlying classes among our participants (RQ1), followed by a multinomial regression, where class membership is predicted using a different set of attitudinal variables (RQ2). We discuss these methods in more detail below.

\subsubsection{Latent Class Analysis}

Using the poLCA package for R [100], a latent class analyses (LCA) was performed. LCA allows for the identification of different groups of respondents (classes), based on the response patterns for a set of manifest variables. Within each class, response patterns for individuals are more similar than response patterns across classes [101]. In accordance with prior research, we preferred LCA as a statistical method as we aimed to identify different types of political participation based on various response patterns [19].

Our LCA was performed on 18 different political participation variables (as presented in Table 1). To ease the interpretation of the LCA, the variables were dichotomized, in accordance with Portos et al. [99]. In contrast to approaches such as k-means, LCA can be used with categorical variables. Following the approach suggested by Lanza et al. [102], we fitted a series of models, successively increasing the number of proposed clusters, ranging from 2 to 10. Bayesian Information Criterion (BIC) is widely proposed as the most robust indicator of preferred class number $[4,17,103]$. In contrast, AIC is described as having low accuracy rates in estimating the correct number of clusters [104] Therefore, we compared BIC for all 10 models, with preference given to the model with the lowest BIC.

\subsubsection{Multinomial Logistic Regression}

In order to assess which factors explain whether someone belongs to a certain activist type, a multinomial logistic regression was performed using SPSS Statistics 26 . In the context of this study, the outcome considered is membership of a certain activist type and, therefore, the classes that emerged from our latent class analysis were used as dependent variable for the regression. Four different types of predictors were included in the analysis: socio-demographic and control variables (such as age, sex and economic strain), political efficacies, a set of variables concerning climate issue involvement, and lastly, different motives for online political expression.

\section{Results}

\subsection{Results Latent Class Analysis}

As noted before, LCA was used to identify unobserved classes among our respondents based on their responses on 18 political participation variables. When employing LCA, first, the optimal number of classes needs to be determined. Table 2 presents the model fit statistics for various class numbers. After inspecting these statistics and the corresponding plots, it was confirmed the four-cluster solution had the lowest BIC. Combined with theoretical considerations, inspecting the proportion of respondents in each class and the 
interpretability of alternative cluster solutions, we identified the four-cluster solution as the optimal model $[18,19,105]$.

Table 2. Model fit statistics for LCA.

\begin{tabular}{cc}
\hline Number of Classes & BIC \\
\hline 2 & 7802.219 \\
3 & 7648.414 \\
4 & 7529.621 \\
5 & 7567.779 \\
6 & 7624.263 \\
7 & 7680.433 \\
8 & 7740.271 \\
9 & 7826.452 \\
\hline
\end{tabular}

The four-cluster solution with bold had the lowest BIC.

Figure 1 is a graphical representation of the conditional item-specific probabilities for the four-cluster model. These indicate the probability that an individual belonging to a certain class would endorse a certain item, that is, how likely someone within that class is to engage in a specific type of participation. Overall, probabilities $<0.30$ and $>0.70$ are considered meaningful and we relied on this information in order to interpret and label the classes [101].

Class

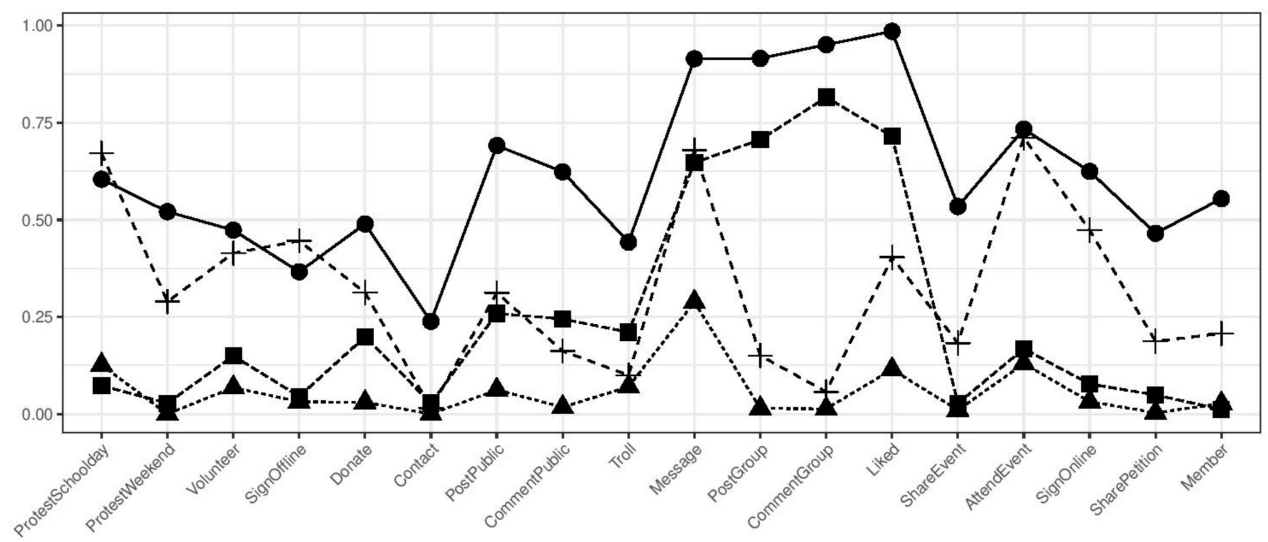

Figure 1. Four classes of activists. Conditional probabilities plotted on $y$-axis, participation items on $x$-axis.

The first class was labelled 'protesters' (16.67\% of our sample). As the name suggests, their repertoire mainly centers around protest participation, both offline and online. Members of this class have about $67 \%$ chance of participating in a protest, march, or manifestation on a school day, while participation in weekends was less popular (item probability $=0.29$ ). Interestingly, the protesters also employed Facebook to signal their engagement, by indicating their attendance to protests through online events (0.71). Furthermore, protesters had a relatively high probability of using Facebook Messenger to communicate on the climate issue (0.68).

The second class, labelled 'all-round activists', is characterized by a more diverse participation pattern (14.26\% of our sample). Again, protesting was the most common offline mode of action. Members of this class have a rather high chance of participating in protests on school days (0.60) and, contrary to any of the other classes, during weekends (0.52), suggesting a more durable engagement. Other forms of offline participation, such as volunteering or donating money, were less likely to occur among the all-round activists with probabilities mirroring those of the first class (between 0.30 and 0.50). In sum, in terms of offline participation, class 2 mainly differs from class 1 in terms of their protest participation on weekends and holidays. 
However, when looking at SNS (social networking site) participation, a more nuanced picture emerges. This class mainly distinguishes itself from the others by their engagement in various participatory acts through Facebook. All-round activists are the only class who show relative high probabilities of posting and commenting publicly on climate-related content ( 0.69 and 0.62 respectively). Their most prominent form of SNS action is engagement in closed Facebook groups on the climate issue as well as instant messaging (probabilities ranging between 0.91 and 0.98). Again, Facebook events make up an important part of the repertoire, complementing the actual participation in protests and marches. 'All-rounders' are, however, the only class who are somewhat likely to actively share and spread these online events (0.53). This group is also unique in their sharing and signing of online petitions, joining Facebook groups and even trolling. While these probabilities remain relatively low, they are substantively higher than those of the other classes.

The third class ('private activists', $19.48 \%$ of our sample) shows a very clear focus on one distinct type of participation: engagement in closed Facebook groups such as posting, commenting, and liking content concerning the climate issue. Members of this class also showed relative high probabilities of using instant messaging in this context (0.64), again emphasizing the rather private character of their acts. Public forms of Facebook participation are considerably less common (with probabilities ranging from 0.21 to 0.25 ). The same is true for other participatory acts, such as participation in the climate protests or signing and sharing petitions.

Finally, the largest group in our sample (49.60\%, 'non-engagers') are young people who are characterized by an overall lack of political participation regarding the climate issue. For most participation types, the members of these clusters have a near zero chance of engaging. Using Facebook Messenger in the context of the climate issue was the most common type of action among the non-engagers, while the probability remains very low compared to the other clusters (0.29).

\subsection{Results Multinomial Logistic Regression}

Table 3 presents the results of the multinomial logistic regression. The reported odds ratio's represent the change in the odds of belonging to a specific class for every unit increase on the predictor variable, compared to the reference category (class 4, 'nonengagers'). Odds ratio's greater than 1 indicate that if the value of the predictor increases, the odds of the outcome occurring (i.e., being a member of a certain class) increase as well. If the odds ratio is smaller than 1 , the odds of the outcome occurring decrease as the values of the predictor increase [106].

Table 3. Multinomial logistic regression analysis predicting class membership.

\begin{tabular}{|c|c|c|c|c|c|c|c|c|c|}
\hline & \multicolumn{3}{|c|}{ Protesters } & \multicolumn{3}{|c|}{ All-Round Activists } & \multicolumn{3}{|c|}{ Private Activists } \\
\hline & B & SE & $\begin{array}{l}\text { Odds } \\
\text { Ratio }\end{array}$ & B & SE & $\begin{array}{l}\text { Odds } \\
\text { Ratio }\end{array}$ & B & SE & $\begin{array}{l}\text { Odds } \\
\text { Ratio }\end{array}$ \\
\hline Intercept & 1.218 & 3.383 & / & -2.468 & 3.814 & / & $-5.907 *$ & 2.814 & / \\
\hline Demographics and controls & & & & & & & & & \\
\hline Sex (being a girl) & $0.719 *$ & 0.322 & 2.052 & -0.264 & 0.372 & 0.768 & $-0.591 *$ & 0.295 & 0.554 \\
\hline Age & $-0.520^{* *}$ & 0.196 & 0.594 & -0.269 & 0.207 & 0.764 & 0.103 & 0.152 & 1.109 \\
\hline Economic strain & 0.255 & 0.170 & 1.290 & 0.344 & 0.184 & 1.410 & 0.106 & 0.153 & 1.112 \\
\hline $\begin{array}{l}\text { School strike policy (evidence of } \\
\text { participation needed) }\end{array}$ & -0.471 & 0.344 & 0.624 & -0.421 & 0.407 & 0.656 & 0.173 & 0.308 & 1.188 \\
\hline $\begin{array}{c}\text { School strike policy (no evidence of } \\
\text { participation needed) } \\
\text { Political efficacies }\end{array}$ & -0.207 & 0.413 & 0.813 & 0.050 & 0.471 & 1.051 & -0.768 & 0.366 & 0.464 \\
\hline Internal political efficacy & 0.166 & 0.167 & 1.181 & $0.474 *$ & 0.187 & 1.607 & 0.074 & 0.142 & 1.077 \\
\hline Collective cause efficacy & -0.198 & 0.204 & 0.820 & -0.276 & 0.237 & 0.759 & 0.127 & 0.163 & 1.136 \\
\hline Social media internal political efficacy & 0.166 & 0.195 & 1.180 & 0.298 & 0.241 & 1.348 & $0.340 *$ & 0.160 & 1.405 \\
\hline Social media collective efficacy & 0.243 & 0.247 & 1.275 & $-0.628 *$ & 0.267 & 0.533 & 0.047 & 0.182 & 1.048 \\
\hline
\end{tabular}


Table 3. Cont.

\begin{tabular}{|c|c|c|c|c|c|c|c|c|c|}
\hline & \multicolumn{3}{|c|}{ Protesters } & \multicolumn{3}{|c|}{ All-Round Activists } & \multicolumn{3}{|c|}{ Private Activists } \\
\hline & B & SE & $\begin{array}{l}\text { Odds } \\
\text { Ratio }\end{array}$ & B & SE & $\begin{array}{l}\text { Odds } \\
\text { Ratio }\end{array}$ & B & SE & $\begin{array}{l}\text { Odds } \\
\text { Ratio }\end{array}$ \\
\hline Issue involvement & & & & & & & & & \\
\hline Ecological worldview & 0.358 & 0.346 & 1.430 & 0.517 & 0.394 & 1.676 & 0.541 & 0.286 & 1.718 \\
\hline Environmental concern & $0.650 * *$ & 0.236 & 1.916 & 0.332 & 0.249 & 1.393 & -0.194 & 0.169 & 0.824 \\
\hline \multicolumn{10}{|c|}{ Motives for political expression online } \\
\hline Informing others & 0.346 & 0.322 & 1.414 & $1.226^{* * *}$ & 0.352 & 3.407 & 0.054 & 0.320 & 1.055 \\
\hline Persuasion & $0.655 *$ & 0.303 & 1.926 & 0.448 & 0.325 & 1.566 & 0.533 & 0.303 & 1.705 \\
\hline Self-presentation & -0.380 & 0.325 & 0.684 & 0.039 & 0.330 & 1.040 & -0.386 & 0.311 & 0.680 \\
\hline
\end{tabular}

Note: $n=498 ; \mathrm{R}^{2}=0.40$ (Cox and Snell), 0.43 (Nagelkerke), 0.20 (McFadden); model $\chi^{2}(42)=250.95, p=0.000 ;{ }^{*} p<0.05 ; * * p 0.01 ;$ *** $p<0.001$

Looking at the role of socio-demographic characteristics, sex was significantly associated with being a protester and a private activist. However, whereas protesters were more likely to be girls, private activists were more likely to be boys, compared to the nonengagers. Age was negatively associated with being a protester, indicating that younger students were more likely to belong to this cluster. In addition, perceived economic strain was not significantly associated with membership of either of the clusters, nor was the school's policy regarding participation in the protests.

Different types of political efficacy showed to have varying effects on young people's participation repertoires regarding the climate issue. Contrary to what we would expect, none of the included efficacies were predictive of becoming a protester over a non-engager. Concerning the all-round activists, who have the most diverse political repertoire, internal political efficacy positively affected the probabilities of being a member of this group. This implies that all-round activists have an overall higher belief that they are capable of influencing government decisions. In turn, a negative association exists between social media collective efficacy and being an all-round activist over a non-engager. This type of efficacy refers to the belief that the climate movement as a whole could achieve certain political goals using social media platforms. Again a different type of efficacy was predictive of becoming a private activist. Young people who have a strong sense that they can employ SNS as a political tool (i.e., social media internal political efficacy) are more likely to be politically active in online groups surrounding the climate issue, compared to non-engagers.

The regression included two indicators of overall involvement with the climate issue. First, environmental concern positively affected the probabilities of belonging to the protester class. In other words, relative to the non-engager class, protesters feel more concerned about the environment and climate change. In addition, endorsement of an ecological worldview showed to be a possible important indicator of being a private activist, over being a non-engager. While the result was non-significant $(p=0.08)$, the odds ratio was rather high (1.72).

As a final set of variables in the regression, we included different motives for online political expression. Specifically, a higher score on the motive of persuasion increases the chances of belonging to the protester class, while the motive of informing others was significantly associated with becoming an all-round activist. In the latter case, the odds were also very high (3.41), indicating that for each unit increase in the informing motive, the odds of becoming an all-round activist increase by a factor of 3.41. Interestingly, no significant associations were found between the self-presentation motive and membership of the different classes.

\section{Discussion}

This study focused on the 2019 youth-led, worldwide climate strikes in order to study how changing notions of citizenship, as well as shifts in the media landscape, are reflected in the participation repertoires of young citizens. Relying on a repertoire-based approach, 
the study used latent class analysis (LCA) to identify different types of climate activists among Belgian high school students $(n=498)$. In addition, we employed multinomial logistic regression to assess why young citizens exert different participation patterns. Four participation repertoires (classes) were identified in our sample, each distinctive in the ways citizens in the classes rely on different participation modes, both offline and through Facebook. Moreover, the results indicate how membership to each of the different classes, relative to being a non-engager, is associated with a unique set of characteristics (in terms of attitudes and motivations). This corresponds with the findings of Portos et al. [99].

About half of our sample belonged to the 'non-engager' class, and thus mainly refrained from climate-related political participation. This corresponds with prior repertoirebased studies, where oftentimes a large group of the study sample are found to be politically 'inactive' or 'disengaged', even when considering a wide array of participatory acts $[17,18,99,107]$. Of course, these findings are highly dependent on the social groups, behaviours, and political causes considered. When considering issue-specific participation, the increasingly polarized and fragmented nature of politics is likely to produce a group of citizens who are not politically active regarding a particular issue, simply because the issue is not deemed relevant [108]. Simultaneously, however, the increasingly flexible nature of political membership combined with the affordances of social media allow these same citizens to start participating, if they would be willing to [29,31].

Our results suggest that protesters who committed to the weekly climate strikes and signaled their engagement through Facebook events were mainly driven by their concerns about climate change. The importance of issue involvement, and concern specifically, is in accordance with other studies focusing on the 2019 climate protests [89,109], as well as with general understandings about issue publics [86]. Somewhat unexpectedly, however, none of the included political efficacies were associated with belonging to the protester class. A possible explanation is that protesters were more driven by social influences than by their efficacy perceptions. As decisions to take part in collective action, especially among youth, are not taken in social isolation, future research should assess the possible social dynamics that underly this specific repertoire [110].

Contrary to the protesters, different types of political efficacy proved to be important in the formation of the repertoires of all-round and private activists. All-round activists are characterized by higher levels of internal political efficacy, while their perceptions of social media collective efficacy are lower. That is, citizens who do not believe that social networking sites (SNS) are an appropriate political tool for the climate movement in general, tend to diversify their individual engagement, given that they feel capable to influence government decisions themselves. Despite their low social media collective efficacy, all-round activists still relied rather heavily on Facebook as a political tool, by posting and commenting on climate-related content, as well as sharing events and petitions.

In turn, the 'private activist' class was characterized by their nearly exclusive online participation through closed Facebook groups as well as instant messaging. Compared to non-engagers, private activists have a high individual sense of social media political efficacy. Given the prominence of SNS participation in their repertoires, this confirms prior research that found how specific forms of efficacy are more likely to explain particular modes of political participation [77]. Indeed, for people to claim their role as political instigators in online groups, there must exist a certain belief that they can employ these spaces and tools accordingly. Arguably, the rather private engagement of these young citizens would hardly fit most accepted definitions of political participation (as public ways to target and influence those in power). However, by being active in dedicated Facebook groups and communicating on the climate issue through instant messaging, they seem similar to what Amnå \& Ekman [111] call 'standby citizens'. These citizens are not disengaged but rather manifest a more latent form of political participation by showing interest in particular issues and staying alert. Because of their awareness and readiness to act, their 'pre-political' involvement might be channeled into other forms of participation in the future [112]. This in turn fits current understandings of citizenship as an increasingly 
personal project in which someone can 'opt in', when they want to $[5,10]$. In any case, more work is required to comprehend the particular characteristics of this group within single-issue movements and gain insight into which factors possibly trigger them to move from latent to manifest forms of participation [112].

By focusing on a high school student sample, we aimed to address an important gap in political participation literature. Past research has often failed to adequately measure political participation both among youth specifically, as well as in a social media context [23,36]. This has resulted in the frequent mislabeling of young people as 'disengaged'. As such, our results contribute to a more nuanced understanding of youth political participation, beyond notions of youth as either mere online 'slacktivists', or as 'apathetic' and 'disengaged' citizens. First, the emergence of the protester and all-round activists class highlight the importance of protest as a participatory mode in the worldwide 'School Strike for Climate' movement [12,13]. By some, the movement was labelled a 'new' climate movement, as it was able to mobilize mainly young people who had no prior experience with this type of activism. Moreover, they broke with prior climate mobilizations by mainly targeting local and national governments and focusing on disobedient action in their repertoires [113]. Our results add to these understandings, as we found that SNS have taken up a prominent role in the repertoires of youth regarding the climate issue. Even among the protesters, who centered their engagement around the weekly strikes, SNS were used to complement their offline engagement. As such, these findings correspond with prior studies emphasizing how SNS function as important tools to coordinate physical protest actions [114], as well as mobilize peers to participate [115] and amplify the movements' message [116].

In general, the political repertoires found in this study challenge the slacktivism narrative, where an unengaged youth is assumed to only participate in low-risk, online activities at the expense of 'real', offline political participation [41]. Recent studies have opposed these claims and argued how overall, youth tend to combine both offline and online forms of participation in their political repertoires, which again contradicts claims about the detrimental nature of so-called 'slacktivism' [46,55]. Indeed, digital modes of political action have become increasingly embedded within (youth) repertoires [55-57]. Consequently, for contemporary social movements, various forms of political action coexist within hybrid spaces, technologies and networks, online and offline [58]. Our study not only confirms these findings, but also adds to the literature by shedding light on the underlying motivations for SNS participation within the climate movement. The motive of self-presentation was not associated with membership of any participation class. This goes against early criticisms about youth engaging in SNS participation merely as a way to impress others and 'feel good about themselves' [42]. Rather, in the case of protesters, Facebook events function as a means of persuasion and possibly, mobilization. All-round activists, on the other hand, mainly rely on Facebook to spread information and raise awareness on the climate issue. Similar findings were reported by Boulianne et al. [11], who found how Twitter was used as an important information tool during the 2019 climate protests, whereas mobilizing tweets were less common. As such, our study supports recent literature emphasizing the importance of SNS as unique mobilization and recruitment infrastructures. These platforms provide a crucial flow of ideas, opportunities, information, and support needed to participate. In other words, they allow citizens to invite and become invited in order to act on a social issue (e.g., through dedicated online groups, protest events, and instant messaging services) [57,117].

\section{Limitations and Conclusions}

Some possible limitations of the study should be acknowledged. First, our study relied on a sample of 498 students. Given that our multinomial regression used cluster membership as an outcome variable, the sample within these subpopulations becomes of relevance. Respectively, our clusters had a sample of 83,71 , and 97, compared to our last cluster and reference category with a sample of 247. Because our model included 14 predictors, the samples within these clusters may have been too low to accurately assess 
the model. As such, we would recommend that future research replicates the current study within a larger sample. In addition, the cross-sectional nature of our data does not allow us to make any causal claims about the different participation types. As a consequence, our results are to be interpreted as a descriptive analysis. Furthermore, we specifically assessed various psychological predictors in relation to young citizens' political repertoires. While this focus responds to a specific call in the literature to evaluate the cognitive pathways leading to citizen participation [22,92], these factors are by no means the only relevant variables to be considered in this regard. Future repertoire-based research should therefore consider how different factors are associated with unique participation patterns. Lastly, our study only included Facebook participation. The platform was chosen as its affordances are especially suited for political participation and the expression of one's political identity (for a discussion see [23]). Given that each SNS platform has specific affordances that possibly facilitate political participation in unique ways [118,119], a future research step would be to assess and compare how different SNS are employed within a single-issue movement. For instance, among youth, it would be especially valuable to implement more visual-oriented platforms such as Instagram and TikTok in future research designs to assess whether similar activists types can be discerned.

Despite these limitations, our study addressed several research gaps within political communication literature and youth studies. Our results offer relevant and unique insights in the different participatory repertoires of young Belgian citizens during the 2019 climate protests, while also addressing the characteristics of different activist types. Not only do our results challenge common understandings about youths' apathy towards politics, they also show how SNS make up a crucial part of their issue-specific participation patterns and how various attitudinal factors (such as different political efficacies) determine the participatory choices that young citizens make.

Author Contributions: Conceptualization, C.W.; methodology, C.W. and P.C.; validation, C.W. and P.C.; formal analysis, C.W. and P.C.; investigation, C.W.; data curation, C.W.; writing-original draft preparation, C.W.; writing-review and editing, P.C., K.P. and M.W.; visualization, C.W. and P.C.; supervision, K.P. and M.W.; project administration, C.W., K.P. and M.W.; funding acquisition, K.P. and M.W. All authors have read and agreed to the published version of the manuscript.

Funding: This research was funded by the Research Fund of Ghent University, grant number BOF.STG.2018.0002.01.

Institutional Review Board Statement: The study was conducted according to the guidelines of the Declaration of Helsinki, and approved by the Ethics Committee of Ghent University, Faculty of Political and Social Sciences.

Informed Consent Statement: Informed consent was obtained from all subjects involved in the study.

Data Availability Statement: The data presented in this study are openly available in openICPSR at https:/ / www.openicpsr.org/openicpsr/project/143821/version/V1/view, accessed on 20 August 2021.

Conflicts of Interest: The authors declare no conflict of interest. The funders had no role in the design of the study; in the collection, analyses, or interpretation of data; in the writing of the manuscript, or in the decision to publish the results.

\section{References}

1. Ekström, M.; Sveningsson, M. Young people's experiences of political membership: From political parties to Facebook groups. Inf. Commun. Soc. 2019, 22, 155-171. [CrossRef]

2. Dalton, R.J. Citizenship norms and the expansion of political participation. Polit. Stud. 2008, 56, 76-98. [CrossRef]

3. Gotlieb, M.R.; Thorson, K. Connected political consumers: Transforming personalized politics among youth into broader repertoires of action. J. Youth Stud. 2017, 20, 1044-1061. [CrossRef]

4. Oser, J. Protest as One Political Act in Individuals' Participation Repertoires: Latent Class Analysis and Political Participant Types. Am. Behav. Sci. 2021, 00027642211021633. [CrossRef]

5. Vromen, A. (Ed.) Digital Citizenship and Political Engagement. In Digital Citizenship and Political Engagement; Interest Groups, Advocacy and Democracy Series; Palgrave Macmillan UK: London, UK, 2017; pp. 9-49, ISBN 978-1-137-48865-7. 
6. Bennett, W.L.; Segerberg, A. The logic of connective action: Digital media and the personalization of contentious politics. Inf. Commun. Soc. 2012, 15, 739-768. [CrossRef]

7. Theocharis, Y. The Conceptualization of Digitally Networked Participation. Soc. Media Soc. 2015, 1, 2056305115610140. [CrossRef]

8. Soler-i-Martí, R. Youth political involvement update: Measuring the role of cause-oriented political interest in young people's activism. J. Youth Stud. 2015, 18, 396-416. [CrossRef]

9. Kahne, J.; Hodgin, E.; Eidman-Aadahl, E. Redesigning Civic Education for the Digital Age: Participatory Politics and the Pursuit of Democratic Engagement. Theory Res. Soc. Educ. 2016, 44, 1-35. [CrossRef]

10. Bang, H. Among everyday makers and expert citizens. In Remaking Governance: Peoples, Politics and the Public Sphere; Newman, J., Ed.; The Policy Press: Bristol, UK, 2005; pp. 159-178.

11. Boulianne, S.; Lalancette, M.; Ilkiw, D. "School Strike 4 Climate": Social Media and the International Youth Protest on Climate Change. Media Commun. 2020, 8, 208-218. [CrossRef]

12. Han, H.; Ahn, S.W. Youth Mobilization to Stop Global Climate Change: Narratives and Impact. Sustainability 2020, 12, 4127. [CrossRef]

13. Kenis, A. Clashing tactics, clashing generations: The politics of the school strikes for climate in Belgium. Polit. Gov. 2021, 9, 135-145.

14. Boulianne, S. Twenty Years of Digital Media Effects on Civic and Political Participation. Communic. Res. 2018, 47, 947-966. [CrossRef]

15. Noland, A. Like, Share, Retweet: Testing Competing Models of the Theory of Planned Behavior to Predict Slacktivism Engagement. J. Nonprofit Public Sect. Mark. 2019, 32, 264-285. [CrossRef]

16. Oser, J.; Hooghe, M.; Marien, S. Is Online Participation Distinct from Offline Participation? A Latent Class Analysis of Participation Types and Their Stratification. Polit. Res. Q. 2013, 66, 91-101. [CrossRef]

17. Oser, J. Assessing How Participators Combine Acts in Their "Political Tool Kits": A Person-Centered Measurement Approach for Analyzing Citizen Participation. Soc. Indic. Res. 2017, 133, 235-258. [CrossRef] [PubMed]

18. Monticelli, L.; Bassoli, M. Precarious voices? Types of "political citizens" and repertoires of action among European youth. Partecip. Confl. 2017, 9, 824-856.

19. Keating, A.; Melis, G. Social media and youth political engagement: Preaching to the converted or providing a new voice for youth? Br. J. Polit. Int. Relat. 2017, 19, 877-894. [CrossRef]

20. Theocharis, Y.; de Moor, J.; van Deth, J.W. Digitally Networked Participation and Lifestyle Politics as New Modes of Political Participation. Policy Internet 2019, 13, 30-53. [CrossRef]

21. Gibson, R.; Cantijoch, M. Conceptualizing and measuring participation in the age of the internet: Is online political engagement really different to offline? J. Polit. 2013, 75, 701-716. [CrossRef]

22. Hoffmann, C.P.; Lutz, C. Digital Divides in Political Participation: The Mediating Role of Social Media Self-Efficacy and Privacy Concerns. Policy Internet 2019, 13, 6-29. [CrossRef]

23. Waeterloos, C.; Walrave, M.; Ponnet, K. Designing and validating the Social Media Political Participation Scale: An instrument to measure political participation on social media. Technol. Soc. 2021, 64, 101493. [CrossRef]

24. De Moor, J.; Marien, S.; Hooghe, M. Why only some lifestyle activists avoid state-oriented politics: A case study in the Belgian environmental movement. Mobil. Int. Q. 2017, 22, 245-264. [CrossRef]

25. Vromen, A.; Xenos, M.A.; Loader, B. Young people, social media and connective action: From organisational maintenance to everyday political talk. J. Youth Stud. 2015, 18, 80-100. [CrossRef]

26. Bennett, W.L. Changing citizenship in the digital age. In Civic Life Online; Bennett, W.L., Ed.; MIT Press: Cambridge, MA, USA, 2008; pp. 1-24.

27. Shehata, A.; Ekstrom, M.; Olsson, T. Developing Self-Actualizing and Dutiful Citizens: Testing the AC-DC Model Using Panel Data Among Adolescents. Communic. Res. 2016, 43, 1141-1169. [CrossRef]

28. Hooghe, M.; Oser, J.; Marien, S. A comparative analysis of 'good citizenship': A latent class analysis of adolescents' citizenship norms in 38 countries. Int. Polit. Sci. Rev. 2014, 37, 115-129. [CrossRef]

29. Mihailidis, P.; Thevenin, B. Media literacy as a core competency for engaged citizenship in participatory democracy. Am. Behav. Sci. 2013, 57, 1611-1622. [CrossRef]

30. Kim, D.H.; Ellison, N.B. From observation on social media to offline political participation: The social media affordances approach. New Media Soc. 2021, 1461444821998346. [CrossRef]

31. Östman, J. Information, expression, participation: How involvement in user-generated content relates to democratic engagement among young people. New Media Soc. 2012, 14, 1004-1021. [CrossRef]

32. Ohme, J. Updating citizenship? The effects of digital media use on citizenship understanding and political participation. Inf. Commun. Soc. 2019, 22, 1903-1928. [CrossRef]

33. Bennett, W.L. The personalization of politics: Political identity, social media, and changing patterns of participation. Ann. Am. Acad. Pol. Soc. Sci. 2012, 644, 20-39. [CrossRef]

34. Gil de Zúñiga, H.; Ardèvol-Abreu, A.; Casero-Ripollés, A. WhatsApp political discussion, conventional participation and activism: Exploring direct, indirect and generational effects. Inf. Commun. Soc. 2019, 24, 201-218. [CrossRef]

35. Brunsting, S.; Postmes, T. Social Movement Participation in the Digital Age: Predicting Offline and Online Collective Action. Small Gr. Res. 2002, 33, 525-554. [CrossRef] 
36. Weiss, J. What is youth political participation? Literature review on youth political participation and political attitudes. Front. Polit. Sci. 2020, 2. [CrossRef]

37. Quintelier, E. Engaging Adolescents in Politics: The Longitudinal Effect of Political Socialization Agents. Youth Soc. 2013, 47, 51-69. [CrossRef]

38. Furlong, A.; Cartmel, F. Young People and Social Change, New Perspectives; Sociology and Social Change; Warde, A., Crossley, N., Eds.; Open University Press: Berkshire, UK, 2006; ISBN 9780335218684

39. Putnam, R.D. Bowling Alone: The Collapse and Revival of American Community; A Touchstone Book; Simon \& Schuster: New York, NY, USA, 2000; ISBN 9780743203043.

40. Farthing, R. The politics of youthful antipolitics: Representing the 'issue' of youth participation in politics. J. Youth Stud. 2010, 13, 181-195. [CrossRef]

41. Christensen, H. Political activities on the Internet: Slacktivism or political participation by other means? First Monday 2011, 16. [CrossRef]

42. Morozov, E. The Net Delusion: The Dark Side of Internet Freedom; PublicAffairs: New York, NY, USA, 2011 ; ISBN 1610391632.

43. Manning, N. 'I mainly look at things on an issue by issue basis': Reflexivity and phronêsis in young people's political engagements. J. Youth Stud. 2013, 16, 17-33. [CrossRef]

44. Lutz, C. A social milieu approach to the online participation divides in Germany. Soc. Media Soc. 2016, 2, 2056305115626749.

45. Sloam, J. Diversity and voice: The political participation of young people in the European Union. Br. J. Polit. Int. Relat. 2016, 18, 521-537. [CrossRef]

46. Andersen, K.; Ohme, J.; Bjarnøe, C.; Bordacconi, M.J.; Albæk, E.; De Vreese, C.H. Generational Gaps in Political Media Use and Civic Engagement: From Baby Boomers to Generation Z; Routledge: London, UK, 2020.

47. Chadwick, A. Digital network repertoires and organizational hybridity. Polit. Commun. 2007, 24, 283-301. [CrossRef]

48. Theocharis, Y.; van Deth, J.W. The continuous expansion of citizen participation: A new taxonomy. Eur. Polit. Sci. Rev. 2018, 10, 139-163. [CrossRef]

49. Tilly, C. Contentious Repertoires in Great Britain, 1758-1834. Soc. Sci. Hist. 1993, 17, 253-280.

50. Van Deth, J.W. Studying political participation: Towards a theory of everything. In Proceedings of the Joint Sessions of Workshops of the European Consortium for Political Research, Grenoble, France, 6-11 April 2001; pp. 6-11.

51. De Moor, J. Lifestyle politics and the concept of political participation. Acta Polit. 2017, 52, 179-197. [CrossRef]

52. Stolle, D.; Hooghe, M.; Micheletti, M. Politics in the supermarket: Political consumerism as a form of political participation. Int. Polit. Sci. Rev. 2005, 26, 245-269. [CrossRef]

53. Literat, I.; Markus, S. 'Crafting a way forward': Online participation, craftivism and civic engagement in Ravelry's Pussyhat Project group. Inf. Commun. Soc. 2020, 23, 1411-1426. [CrossRef]

54. Bakker, T.P.; De Vreese, C.H. Good news for the future? Young people, Internet use, and political participation. Communic. Res. 2011, 38, 451-470. [CrossRef]

55. Boulianne, S.; Theocharis, Y. Young people, digital media, and engagement: A meta-analysis of research. Soc. Sci. Comput. Rev. 2018, 38, 111-127. [CrossRef]

56. Elliott, T.; Earl, J. Organizing the next generation: Youth engagement with activism inside and outside of organizations. Soc. Media Soc. 2018, 4, 2056305117750722. [CrossRef]

57. Maher, T.V.; Earl, J. Barrier or Booster? Digital Media, Social Networks, and Youth Micromobilization. Sociol. Perspect. 2019, 62, 865-883. [CrossRef]

58. Duarte, J.M.S. The Net as a space for political militancy: Technology and participation in the electoral campaign. Commun. Soc. 2016, 29, 33-47. [CrossRef]

59. Lane, D.S. Social media design for youth political expression: Testing the roles of identifiability and geo-boundedness. New Media Soc. 2019, 22, 1394-1413. [CrossRef]

60. Literat, I.; Kligler-Vilenchik, N. Youth collective political expression on social media: The role of affordances and memetic dimensions for voicing political views. New Media Soc. 2019, 21, 1988-2009. [CrossRef]

61. Vandendriessche, K.; Steenberghs, E.; Matheve, A.; Georges, A.; De Marez, L. Imec: Digimeter 2020: Digitale Trends in Vlaanderen; Imec: Ghent, Belgium, 2021.

62. Vanhaelewyn, B.; Waeterloos, C.; Joris, G.; Martens, M.; De Wolf, R.; De Leyn, T.; Van Ouytsel, J.; Vandenbussche, E.; Callens, J.; Van Hecke, M.; et al. Onderzoeksrapport Apestaartjaren: De Digitale Leefwereld van Jongeren; Mediaraven: Ghent, Belgium, 2020.

63. Kenski, K.; Stroud, N.J. Connections between Internet use and political efficacy, knowledge, and participation. J. Broadcast. Electron. Media 2006, 50, 173-192. [CrossRef]

64. Bandura, A. Self-efficacy mechanism in human agency. Am. Psychol. 1982, 37, 122-147. [CrossRef]

65. Bandura, A. Self-efficacy: Toward a unifying theory of behavioral change. Psychol. Rev. 1977, 84, 191. [CrossRef]

66. Bandura, A. Social cognitive theory: An agentic perspective. Annu. Rev. Psychol. 2001, 52, 1-26. [CrossRef]

67. Niemi, R.G.; Craig, S.C.; Mattei, F. Measuring internal political efficacy in the 1988 National Election Study. Am. Polit. Sci. Rev. 1991, 85, 1407-1413. [CrossRef]

68. Halpern, D.; Valenzuela, S.; Katz, J.E. We face, I tweet: How different social media influence political participation through collective and internal efficacy. J. Comput. Commun. 2017, 22, 320-336. [CrossRef] 
69. Solhaug, T. Knowledge and Self-Efficacy as Predictors of Political Participation and Civic Attitudes: With Relevance for Educational Practice. Policy Future Educ. 2006, 4, 265-278. [CrossRef]

70. Wilkins, D.J.; Livingstone, A.G.; Levine, M. All click, no action? Online action, efficacy perceptions, and prior experience combine to affect future collective action. Comput. Hum. Behav. 2019, 91, 97-105. [CrossRef]

71. Yu, R.P. The relationship between passive and active non-political social media use and political expression on Facebook and Twitter. Comput. Hum. Behav. 2016, 58, 413-420. [CrossRef]

72. Jung, N.; Kim, Y.; De Zúniga, H.G. The mediating role of knowledge and efficacy in the effects of communication on political participation. Mass Commun. Soc. 2011, 14, 407-430. [CrossRef]

73. Reichert, F. How internal political efficacy translates political knowledge into political participation: Evidence from Germany. Eur. J. Psychol. 2016, 12, 221. [CrossRef]

74. Maurissen, L. Political efficacy and interest as mediators of expected political participation among Belgian adolescents. Appl. Dev. Sci. 2020, 24, 339-353. [CrossRef]

75. Levy, B.L.M.; Akiva, T. Motivating Political Participation Among Youth: An Analysis of Factors Related to Adolescents' Political Engagement. Polit. Psychol. 2019, 40, 1039-1055. [CrossRef]

76. Gil de Zúñiga, H.; Diehl, T.; Ardèvol-Abreu, A. Internal, external, and government political efficacy: Effects on news use, discussion, and political participation. J. Broadcast. Electron. Media 2017, 61, 574-596. [CrossRef]

77. Velasquez, A.; LaRose, R. Social media for social change: Social media political efficacy and activism in student activist groups. J. Broadcast. Electron. Media 2015, 59, 456-474. [CrossRef]

78. Chen, C.; Bai, Y.; Wang, R. Online political efficacy and political participation: A mediation analysis based on the evidence from Taiwan. New Media Soc. 2019, 21, 1667-1696. [CrossRef]

79. Velasquez, A.; LaRose, R. Youth collective activism through social media: The role of collective efficacy. New Media Soc. 2015, 17, 899-918. [CrossRef]

80. Ho, S.S.; Binder, A.R.; Becker, A.B.; Moy, P.; Scheufele, D.A.; Brossard, D.; Gunther, A.C. The Role of Perceptions of Media Bias in General and Issue-Specific Political Participation. Mass Commun. Soc. 2011, 14, 343-374. [CrossRef]

81. Petty, R.E.; Cacioppo, J.T. Issue involvement can increase or decrease persuasion by enhancing message-relevant cognitive responses. J. Pers. Soc. Psychol. 1979, 37, 1915-1926. [CrossRef]

82. Guo, L.; Su, C.; Lee, H. Effects of Issue Involvement, News Attention, Perceived Knowledge, and Perceived Influence of Anti-Corruption News on Chinese Students' Political Participation. J. Mass Commun. Q. 2018, 96, 452-472. [CrossRef]

83. Nekmat, E.; Ismail, I. Issue-based micromobilization on social media: Mediated pathways linking issue involvement and self-network opinion congruity to expressive support. Comput. Hum. Behav. 2019, 101, 51-59. [CrossRef]

84. Kim, Y.M. Issue Publics in the New Information Environment: Selectivity, Domain Specificity, and Extremity. Communic. Res. 2009, 36, 254-284. [CrossRef]

85. Lo, V.-H.; Wei, R.; Lu, H.-Y. Issue Importance, Third-Person Effects of Protest News, and Participation in Taiwan's Sunflower Movement. J. Mass Commun. Q. 2016, 94, 682-702. [CrossRef]

86. Hestres, L.E. Preaching to the choir: Internet-mediated advocacy, issue public mobilization, and climate change. New Media Soc. 2013, 16, 323-339. [CrossRef]

87. Roser-Renouf, C.; Maibach, E.W.; Leiserowitz, A.; Zhao, X. The genesis of climate change activism: From key beliefs to political action. Clim. Chang. 2014, 125, 163-178. [CrossRef]

88. Halkos, G.; Gkargkavouzi, A.; Matsiori, S. A multi-dimensional measure of environmental behavior: Exploring the predictive power of connectedness to nature, ecological worldview and environmental concern. Soc. Indic. Res. 2018, 143, 859-879.

89. Brügger, A.; Gubler, M.; Steentjes, K.; Capstick, S.B. Social Identity and Risk Perception Explain Participation in the Swiss Youth Climate Strikes. Sustainability 2020, 12, 10605. [CrossRef]

90. Stevenson, K.T.; Nils Peterson, M.; Bondell, H.D. Developing a model of climate change behavior among adolescents. Clim. Chang. 2018, 151, 589-603. [CrossRef]

91. Dunlap, R.E.; Van Liere, K.D.; Mertig, A.G.; Jones, R.E. New Trends in Measuring Environmental Attitudes: Measuring Endorsement of the New Ecological Paradigm: A Revised NEP Scale. J. Soc. Issues 2000, 56, 425-442. [CrossRef]

92. Earl, J.; Copeland, L.; Bimber, B. Routing around Organizations: Self-Directed Political Consumption. Mobil. Int. Q. 2017, 22, 131-153. [CrossRef]

93. Bimber, B. Information and political engagement in America: The search for effects of information technology at the individual level. Polit. Res. Q. 2001, 54,53-67. [CrossRef]

94. Macafee, T. Some of these things are not like the others: Examining motivations and political predispositions among political Facebook activity. Comput. Hum. Behav. 2013, 29, 2766-2775. [CrossRef]

95. Gil de Zúñiga, H.; Valenzuela, S.; Weeks, B.E. Motivations for political discussion: Antecedents and consequences on civic engagement. Hum. Commun. Res. 2016, 42, 533-552. [CrossRef]

96. Winter, S.; Neubaum, G. Examining characteristics of opinion leaders in social media: A motivational approach. Soc. Media Soc. 2016, 2, 2056305116665858. [CrossRef]

97. Wadsworth, M.E.; Compas, B.E. Coping with family conflict and economic strain: The adolescent perspective. J. Res. Adolesc. 2002, 12, 243-274. [CrossRef] 
98. Ponnet, K.; Wouters, E. Stress and mental health in families with different income levels: A strategy to collect multi-actor data. JMIR Res. Protoc. 2014, 3, e2832. [CrossRef]

99. Portos, M.; Bosi, L.; Zamponi, L. Life beyond the ballot box: The political participation and non-participation of electoral abstainers. Eur. Soc. 2019, 22, 231-265. [CrossRef]

100. Linzer, D.A.; Lewis, J.B. poLCA: An R Package for Polytomous Variable Latent Class Analysis. J. Stat. Softw. 2011, 42, 1-29. [CrossRef]

101. Masyn, K.E. Latent Class Analysis and Finite Mixture Modeling. In The Oxford Handbook of Quantitative Methods, Volume 2: Statistical Analysis; Little, T.D., Ed.; Oxford University Press: Oxford, UK, 2013; pp. 551-611. ISBN 978-0-19-993487-4.

102. Lanza, S.T.; Collins, L.M.; Lemmon, D.R.; Schafer, J.L. PROC LCA: A SAS Procedure for Latent Class Analysis. Struct. Equat. Model. A Multidiscip. J. 2007, 14, 671-694. [CrossRef]

103. Nylund, K.L.; Asparouhov, T.; Muthén, B.O. Deciding on the Number of Classes in Latent Class Analysis and Growth Mixture Modeling: A Monte Carlo Simulation Study. Struct. Equat. Model. A Multidiscip. J. 2007, 14, 535-569. [CrossRef]

104. Yang, C.-C. Evaluating latent class analysis models in qualitative phenotype identification. Comput. Stat. Data Anal. 2006, 50, 1090-1104. [CrossRef]

105. Nasserinejad, K.; van Rosmalen, J.; de Kort, W.; Lesaffre, E. Comparison of Criteria for Choosing the Number of Classes in Bayesian Finite Mixture Models. PLoS ONE 2017, 12, e0168838. [CrossRef] [PubMed]

106. Field, A. Discovering Statistics Using IBM SPSS Statistics; Sage: Los Angeles, CA, USA, 2013; ISBN 1446274586.

107. Fu, K.; Wong, P.W.C.; Law, Y.W.; Yip, P.S.F. Building a typology of young people's conventional and online political participation: A randomized mobile phone survey in Hong Kong, China. J. Inf. Technol. Polit. 2016, 13, 126-141. [CrossRef]

108. Vraga, E.K.; Anderson, A.A.; Kotcher, J.E.; Maibach, E.W. Issue-Specific Engagement: How Facebook Contributes to Opinion Leadership and Efficacy on Energy and Climate Issues. J. Inf. Technol. Polit. 2015, 12, 200-218. [CrossRef]

109. Martiskainen, M.; Axon, S.; Sovacool, B.K.; Sareen, S.; Furszyfer Del Rio, D.; Axon, K. Contextualizing climate justice activism: Knowledge, emotions, motivations, and actions among climate strikers in six cities. Glob. Environ. Chang. 2020, 65, 102180. [CrossRef]

110. Rees, J.H.; Bamberg, S. Climate protection needs societal change: Determinants of intention to participate in collective climate action. Eur. J. Soc. Psychol. 2014, 44, 466-473. [CrossRef]

111. Amnå, E.; Ekman, J. Standby citizens: Diverse faces of political passivity. Eur. Polit. Sci. Rev. 2014, 6, 261-281. [CrossRef]

112. Ekman, J.; Amnå, E. Political participation and civic engagement: Towards a new typology. Hum. Aff. 2012, 22, 283-300. [CrossRef]

113. De Moor, J.; De Vydt, M.; Uba, K.; Wahlström, M. New kids on the block: Taking stock of the recent cycle of climate activism. Soc. Mov. Stud. 2020, 20, 1-7. [CrossRef]

114. Jost, J.T.; Barberá, P.; Bonneau, R.; Langer, M.; Metzger, M.; Nagler, J.; Sterling, J.; Tucker, J.A. How Social Media Facilitates Political Protest: Information, Motivation, and Social Networks. Polit. Psychol. 2018, 39, 85-118. [CrossRef]

115. Nekmat, E.; Gower, K.K.; Gonzenbach, W.J.; Flanagin, A.J. Source effects in the micro-mobilization of collective action via social media. Inf. Commun. Soc. 2015, 18, 1076-1091. [CrossRef]

116. Earl, J. Something old and something new: A comment on "new media, new civics". Policy Internet 2014, 6, 169-175. [CrossRef]

117. Crossley, A.D. Facebook Feminism: Social Media, Blogs, and New Technologies of Contemporary U.S. Feminism. Mobil. Int. Q. 2015, 20, 253-268. [CrossRef]

118. Kim, C.; Lee, S. Does social media type matter to politics? Investigating the difference in political participation depending on preferred social media sites. Soc. Sci. Q. 2021. [CrossRef]

119. Lee, F.L.F.; Liang, H.; Cheng, E.W.; Tang, G.K.Y.; Yuen, S. Affordances, movement dynamics, and a centralized digital communication platform in a networked movement. Inf. Commun. Soc. 2021, 2021, 1-18. [CrossRef] 